1 Meerstadt PWD. Atropine poisoning in early infancy due to eumydrin drops. Br Med F 1982;285:196-7.

2 Wade A, ed. Martindale's extra pharmacopoeia. 27th ed. London: The Pharmaceutical Press, 1977.

${ }^{3}$ Kalser SC, MacLean PL. Atropine metabolism in man. Clin Pharacol Ther 1970;11:214-27.

${ }^{4}$ Bochner F, Carruthers G, Kampmann J, Stiner J. Handbook of clinical pharmacology. 1st ed. Boston: Little Brown and Co, 1978.

${ }^{5}$ Sayffart G, ed. Poison index. 1st ed. Bad Homburg: Fresenius Foundation, 1977.

(Accepted 7 April 1983)

Department of Renal Medicine, St James's University Hospital, Leeds LS9 7TF

D P WORTH, MB, MRCP, registrar

A M DAVISON, MD, FRCP, consultant renal physician

T G ROBERTS, MB, MRCP, registrar

A M LEWINS, SRN, nursing officer

Correspondence to: Dr A M Davison.

\section{Chronic graft versus host disease presenting with polymyositis}

Chronic graft versus host disease after bone marrow transplant affects many organ systems, particularly the skin, upper gastrointestinal tract, eye, and liver. ${ }^{12}$ It can also cause syndromes akin to collagen vascular disease, ${ }^{2}{ }^{3}$ suggesting a common pathogenesis.

We report a patient who developed polymyositis as the only manifestation of chronic graft versus host reaction seven months after bone marrow transplant.

\section{Case report}

An 11 year old boy presented with acute lymphoblastic leukaemia in January 1977 and after treatment with the UKALL V (United Kingdom Acute Lymphoblastic Leukaemia (trial) V) regimen remained in remission until January 1980. A second remission was achieved with the same regimen. In January 1981 he again relapsed and remitted a third time, but the course was complicated by herpes zoster which responded to acyclovir.

An HLA matched, mixed lymphocyte culture non-reactive bone marrow transplant from his mother was performed in April 1981. Pregraft preparation included methyl prednisolone, vincristine, zoster immune globulin, and oral amphotericin followed by cyclosporin A, cyclophosphamide, and total body irradiation. The graft contained $3.5 \times 10^{8}$ nucleated cells $/ \mathrm{kg}$ and graft reconstruction showed 500 neutrophils on day 20 and 1000 neutrophils on day 31. Chromosomes were $100 \%$ female. Graft versus host prophylaxis after bone marrow transplant included methotrexate and cyclosporin $\mathrm{A}$

On day 7 after the bone marrow transplant he had an infection over the site of the deep intravenous line, which improved after treatment with antibiotics and one unit of buffy coat cells, and on day 8 he developed oral herpes which responded to acyclovir and zoster immune globulin. On day 10 he developed acute graft versus host disease with pyrexia and shivering, a rash on his face, palms, soles, legs, and trunk, and loose stools. This responded to intravenous hydrocortisone and eight days' treatment with oral prednisolone. On day 35 his symptoms recurred and responded to prednisolone given for three days. He was discharged from the bone marrow transplant unit taking maintenance cyclosporin $\mathrm{A}$ and oral amphotericin and returned to normal activities. By September 1981 he was no longer taking any medication, back at school, and in good health.

In November 1981 he had an upper respiratory tract infection followed by swelling of his ankles and inability to straighten his arms. Over the next week he became too weak to run, jump, or get up from the floor and had extreme muscle tenderness. Bone marrow showed no relapse. Serum creatine kinase activity was $1750 \mathrm{IU} / \mathrm{l}$ (normal $<200 \mathrm{IU} / \mathrm{l}$ ) and he was referred to our muscle clinic. He was generally unwell and miserable. His skin was dry but without rash or discoloration. He had no breathing or swallowing difficulties. He could get up from a low chair, walk, and climb stairs but had difficulty in getting up off the floor and could not hop on one leg. The calves were tender. There were flexion contractures of the elbows and mild pitting oedema of the ankles.
The clinical features were typical of childhood dermatomyositis but without apparent skin manifestations. The serum creatine kinase activity was $3950 \mathrm{IU} / 1$; the electromyogram was abnormal with fibrillation potentials and a high proportion of polyphasic complexes, and needle biopsy of the quadriceps showed unequivocal pathological change with focal degenerating fibres, angulated atrophic fibres, and cellular response, partly perivascular. There was no perifascicular atrophy. Electron microscopy showed no evidence of viral inclusion bodies. Viral antibody titres (cytomegalovirus and Coxsackie group) were not raised except for Coxsackie B3 (1/1024), which was unchanged six weeks later. A toxoplasma dye test was negative. He was treated with ora prednisolone $1 \mathrm{mg} / \mathrm{kg} /$ day in divided doses. After clinical improvement two weeks later the daily dose was gradually reduced by $2.5 \mathrm{mg}$ every fortnight until it reached $10 \mathrm{mg} /$ day and then by $1 \mathrm{mg}$ every fortnight.

After two months he was considerably better and more active and the serum creatine kinase activity had fallen to $650 \mathrm{IU} / 1$. His condition remained fairly static until May 1982, when there was increased stiffness of the arms, some decline in muscle function, and a rise in serum creatine kinase activity to $1590 \mathrm{IU} / 1$. In June he was readmitted with an acute respiratory infection and increase in muscle weakness. There was skin depigmentation, lichen planus in the mouth, and also herpes labialis. Chest $x$ ray films showed left lower lobe collapse and a large right paratracheal mediastinal mass. He was treated with acyclovir, erythromycin, piperacillin, intravenous amphotericin, and methylprednisolone ( $1 \mathrm{~g} / \mathrm{m}^{2}$ twice daily) and also cyclosporin $\mathrm{A}$, antilymphocyte globulin, and intravenous cyclophosphamide. After an initial slight improvement his condition steadily deteriorated; he had severa convulsions and died on $16 \mathrm{July}$. There was no evidence of leukaemic recurrence in the blood, bone marrow, or cerebrospinal fluid. All efforts to identify a viral infection were negative. Permission for necropsy was refused

\section{Comment}

Although reports of chronic graft versus host disease after bone marrow transplant have included myositis as a late component of the disease complex,,$^{23}$ the present case is unusual in that polymyositis was the only manifestation of graft versus host disease. This raises the possibility of some selectivity of the immune process for muscle antigens rather than a more general involvement of aggressive $T$ cells against various tissues. Cell mediated cytotoxicity has been implicated in polymyositis ${ }^{4}$ and the $\mathrm{T}$ lymphocytes were thought to be involved.

There is evidence that some cases of polymyositis may be initiated by viral infection. Although our patient had clinical evidence suggesting a viral illness before the onset of his myositis, we were unable to identify any viral basis for his initial or terminal illness despite extensive investigations. The high titre of antibody to Coxsackie B3 was considered to reflect a previous viral infection rather than being causally related, as it was unchanged several weeks later.

NP is a clinical research fellow of the American Muscular Dystrophy Association. We thank Dr K Hugh-Jones, Westminster Children's Hospital, for referring the patient and for details of his management, Drs E C GordonSmith and R O'Reilly for advice, and Dr J Heckmatt, Mrs Christine Hutson, Mr P Richards, and Dr G Cambridge for help with the investigations. Our muscle research programme is supported by the Muscular Dystrophy Group of Great Britain.

1 Slavin RE, Santos GW. The graft-versus-host reaction in man after bone marrow transplantation: pathology, pathogenesis, clinical features and implication. Clin Immunol Immunopathol 1973;1:472-98.

2 Shulman HM, Sullivan KM, Weiden PL, et al. Chronic graft-versus-host syndrome in man. Am F Med 1980;69:204-17.

${ }^{3}$ Anderson BA, Young $\mathrm{P}$, Kean WF, et al. Polymyositis in chronic graftversus-host disease. Arch Neurol $1982 ; 39: 188-90$.

4 Dawkins RL, Mastaglia FL. Cell-mediated cytotoxicity to muscle in polymyositis. $N$ Engl f Med 1973;288:434-8.

${ }^{5}$ Rowe DJ, Isenberg DA, McDougall J, et al. Characterization of polymyositis infiltrates using monoclonal antibodies to human leucocyte antigens. Clin Exp Immunol $1981 ; 45: 290-8$.

(Accepted 7 April 1983)

Department of Paediatrics and Neonatal Medicine, Hammersmith Hospital, London W12 0HS

N PIER, MD, clinical research fellow

V DUBOWITZ, MD, PHD, FRCP, DCH, professor of paediatrics

Correspondence to: Professor V Dubowitz. 